\title{
Testing the swash exclusion hypothesis in sandy beach populations: the mole crab Emerita brasiliensis in Uruguay
}

\author{
Omar Defeo $^{1,2}$, Julio Gomez ${ }^{1}$, Diego Lercari ${ }^{1, *}$ \\ ${ }^{1}$ UNDECIMAR, Facultad de Ciencias, Iguá 4225, PO Box 10773, 11400 Montevideo, Uruguay \\ ${ }^{2}$ CINVESTAV-IPN Unidad Mérida, AP 73 Cordemex, 97310 Mérida, Yucatán, Mexico
}

\begin{abstract}
Exposed marine beaches are physically rigorous habitats in which macrofauna community patterns have been well correlated with physical factors such as grain size, beach slope and wave/swash processes. In this context, the swash exclusion hypothesis (SEH) gained wide acceptability in explaining the control of species abundance and diversity of the sandy beach macrofauna by swash climate, determined by wave height and beach face slope. This hypothesis predicts a consistent increase in species richness, abundance and biomass from reflective to dissipative conditions. However, predictions of the SEH have not been adequately tested at a population level. Here, demographic and life history characteristics of the intertidal mole crab Emerita brasiliensis were compared between populations of 2 microtidal exposed sandy beaches with contrasting morphodynamics during 22 consecutive months. The major prediction of the paradigm does not hold for the mole crab: total abundance, as well as that of males, females, males with spermatophores and megalops did not differ between beaches. Moreover, the reflective beach population presented higher male growth rates in size and lower natural mortality. Other population processes and life history traits gave support for the SEH: the dissipative beach population presented (1) higher abundance of ovigerous females, female growth rates, fecundity, egg production potential, size at maturity, as well as weight at size; and (2) lower female mortality and burrowing rates (for both sexes). The SEH seems to be particularly useful in explaining female somatic growth and reproductive features, which could be related to a major amount of food availability in dissipative beaches. However, other competing, but not exclusive, hypotheses are needed to explain variations in population abundance and other processes such as male growth and survivorship. The empirical evidence from several recent studies on the Uruguayan coast showed that sandy beach populations that co-occur in contrasting environments are less sensitive to variations in beach morphodynamics, which should not be considered the primary factor affecting the abundance and some life history traits. The importance of alternative population regulation processes and mechanisms are stressed.
\end{abstract}

KEY WORDS: Mole crab · Emerita brasiliensis - Swash exclusion hypothesis · Population demography $\cdot$ Population regulation $\cdot$ Life history $\cdot$ Sandy beaches $\cdot$ Beach morphodynamics $\cdot$ Uruguay

\section{INTRODUCTION}

Microtidal sandy beaches constitute widely fluctuating environments which have been classified into 3

\footnotetext{
*Corresponding author. E-mail: lercari@fcien.edu.uy
}

distinctive types according to breaker wave height, wave period and sediment size: reflective, intermediate and dissipative (see review in Short 1996). Reflective beaches have coarse sand, short swash periods, steep slopes, high substrate penetrability, low organic matter and low sediment water content. Dissipative beaches are defined by fine sands, flat slopes, low sub- 
strate penetrability, and high water content. Resident macrobenthic communities have been shown to be mainly regulated by these sedimentary parameters and wave/swash processes and thus match well with this physical classification of sandy beaches. In this context, the swash exclusion hypothesis (SEH) states that swash climate, mainly influenced by wave height and beach slope, is the key variable controlling the intertidal sandy beach macrofauna (McLachlan et al. 1993, 1995). Swash climate is considered most benign on dissipative beaches and becomes harsher towards more reflective conditions, where more species are excluded until, in the extreme reflective situation, no intertidal species occur and only supralittoral forms remain (McLachlan et al. 1995). This prediction seems to be valid world-wide: species diversity, total abundance and biomass increase from reflective to dissipative beaches, both for species living in and even outside (supralittoral) the swash climate (McLachlan 1990, Defeo et al. 1992b, McLachlan et al. 1993, Borzone et al. 1996, Ricciardi \& Bourget 1999).

Observations in sandy beaches have been readily interpreted as conforming to the predictions from the above paradigm derived from studies on a community level. This generated theory ladenness (sensu Underwood 1990) in data acquisition about patterns in previously unexamined systems has been reflected by the rarity of pertinent hypotheses concerning predictions of population patterns. Thus, despite significant work examining community level responses to beach morphodynamics, there are no detailed studies that investigate how the species respond to the swash climate in demographic terms, i.e., whether the abundance, individual growth, mortality, fecundity and other population dynamic features undergo changes according to sandy beach characteristics. McLachlan et al. (1995) showed that the SEH holds partially true for 12 bivalve species sampled from 4 continents. They concluded that, contrary to the predictions of the SEH, burrowing rates showed little clear pattern in relation to beach type. Gómez \& Defeo (1999) evaluated the effect of morphodynamics on main demographic characteristics of the sandhopper Pseudorchestoidea brasiliensis, in order to test the hypothesis of increasing abundance from reflective to dissipative beaches at the population level. In contrast to this hypothesis, the sandhopper at a reflective beach presented higher abundance, egg production potential and recruitment levels and lower natural mortality. Moreover, no major differences in individual growth and life span were found. The authors concluded that critical life history and demographic features, notably abundance, were not explained in terms of beach morphodynamics.

The intertidal mole crab Emerita brasiliensis (Crustacea: Anomura: Hippidae) occurs in reflective and dissipative sandy beaches along the Atlantic coast of South America, from Venezuela to Uruguay (Efford 1976, Defeo et al. 1992b, Peluffo 1998). Its common occurrence on Uruguayan sandy beaches with contrasting morphodynamics provides the opportunity to evaluate the response of population demography and life history traits in distinct environments. In this paper we compared the abundance, structure, dynamics and life history characteristics of E. brasiliensis populations that inhabit 2 Uruguayan exposed sandy beaches, one dissipative and the other reflective. We argue that the more demanding swash climate on reflective beaches would require organisms to divert more energy to the maintenance of processes other than reproduction and growth (McLachlan et al. 1995). Thus, the following set of predictions was derived from the SEH and tested: the mole crab population at the reflective beach should have (1) lower abundance, individual sizes, growth rates, longevity, weight, fecundity and reproductive output, and (2) higher mortality and burrowing rates. It must be highlighted that most of these predictions on reproductive sizes, fecundity, growth and mortality rates concern the population level, and therefore constitute new additions to the original SEH hypothesis, which was originally formulated on a community level.

\section{METHODS}

Habitat. Two exposed microtidal (tide range $=0.5 \mathrm{~m}$ ) sandy beaches of Uruguay were considered in this paper: Barra del Chuy $\left(33^{\circ} 45^{\prime} \mathrm{S}, 53^{\circ} 27^{\prime} \mathrm{W}\right)$ and Arachania $\left(34^{\circ} 36^{\prime} \mathrm{S}, 53^{\circ} 44^{\prime} \mathrm{W}\right)$. Barra del Chuy is a wide (beach width ca $70 \mathrm{~m}$ ) dissipative beach with fine to very fine (grain size $=0.20 \mathrm{~mm}$ ) well-sorted sands, a gentle slope $(3.53 \%)$, a wide surf zone and high macrofauna richness, total abundance and biomass. Arachania is a reflective beach (width ca $40 \mathrm{~m}$ ) with coarse sediments (grain size $=0.56 \mathrm{~mm})$, steep slope $(7.80 \%$ ), and macrofauna richness 5 times lower than Barra del Chuy. A full characterization of the properties of both beaches is detailed in Defeo et al. $(1992 b, 1997)$ and Gómez \& Defeo (1999: see their Table 1).

Sampling procedures and data analysis. Samples of mole crabs were collected during 22 consecutive months, from March 1996 through December 1997, according to a systematic design. Five transects were set up perpendicular to the shoreline and spaced $8 \mathrm{~m}$ apart. Sampling units (SUs) on each transect were done every $4 \mathrm{~m}$ with a sheet metal cylinder, $27 \mathrm{~cm}$ in diameter and $40 \mathrm{~cm}$ deep, from the base of the dunes to the seaward limit of the mole crab distribution, until at least 2 consecutive SUs yielded no mole crabs. More than 75 SUs were taken during each month. The organisms retained after sieving through a $0.5 \mathrm{~mm}$ 
mesh were fixed and, in the laboratory, measured to the nearest $0.5 \mathrm{~mm}$ carapace length (CL), i.e., from the tip of the rostrum to the distal scoop of the cephalothorax. Afterwards, mole crabs were dried at $50^{\circ} \mathrm{C}$ for $24 \mathrm{~h}$ and weighed to the nearest $0.001 \mathrm{~g}$.

Mole crabs were classified as megalops (non-adults) and adults. Megalops were those with an undeveloped ocular peduncle and presence of plumose pleopods (Veloso \& Cardoso 1999). The sex of each adult was determined and sorted into males with and without spermatophores, females without eggs (hereafter females) and ovigerous females. Species abundance was estimated by the number per strip transect (IST, ind. $\mathrm{m}^{-1}$ ) according to Defeo $(1993,1998)$. Data discriminated by population component were tested for normality and homoscedasticity and compared by 2-sample $t$-tests (Zar 1999). A root-root transformation was employed to stabilize variances.

To estimate fecundity, ovigerous females were collected during the peak of the reproductive season. Crabs were measured, weighed and washed in fresh tap water. Eggs were then removed from the pleopods. The diameters of 30 eggs were measured with a micrometer eyepiece and, assuming a perfect sphere, a mean egg volume was calculated for each ovigerous crab. The total mass was immersed in distilled water and drained over a $25 \mu \mathrm{m}$ mesh by means of a vacuum pump at $0.30 \mathrm{~atm}$ for $1 \mathrm{~min}$ (Diaz et al. 1983). The total drained egg mass was placed into a $10 \mathrm{ml}$ calibrated flask and then filled by means of a $0.01 \mathrm{ml}$ precision electronic buret (Lercari \& Defeo 1999). The total egg mass volume was calculated as the difference between the volume of the calibrated flask and the amount of water added, and the total number of eggs per female was estimated as the ratio between egg mass volume and mean egg volume. The length (CL)-fecundity $(F)$ relationship was estimated by the power function of the form

$$
F=C \cdot \mathrm{CL}^{d}
$$

where $c$ and $d$ are parameters. An ANCOVA was used to compare the CL-F relationship fitted for mole crab females at Arachania and Barra del Chuy.

Monthly length frequency distributions (LFDs) discriminated by sex were used to estimate growth patterns of Emerita brasiliensis. We followed the procedure suggested by Gómez \& Defeo (1999) and briefly summarized here: (1) for each month and sex, we separated normally distributed components of LFDs by maximum likelihood, through the routine NORMSEP (Gayanilo et al. 1996); (2) as we followed each cohort through its entire life span, we were able to assign absolute ages to respective cohorts (lengths) and thus to build an age-length key. Time 0 (birthday) was defined as the minimum size at recruitment of a mole crab to the beach (ca $3 \mathrm{~mm} \mathrm{CL}$ ), and thus subsequent ages were assigned from time 0 , taking into account the date of the $i$ th sample, measured as a portion of the year; and (3) the resulting age-length key for each sex and beach was used to fit the von Bertalanffy growth function (VBGF: Gayanilo et al. 1996) by non-linear least squares:

$\mathrm{CL}_{t}=L_{\infty}\left[1-\mathrm{e}^{\left[-K\left(t-t_{0}\right)+(K C / 2 \pi) \sin 2 \pi(t-W P)-(K C / 2 \pi) \sin 2 \pi\left(t_{0}-W P\right)\right]}\right](2)$

where $\mathrm{CL}_{t}$ is the carapace length at age $t, L_{\infty}$ is the asymptotic length, $K$ is the curvature parameter, $t_{0}$ is the computed age at length zero, $C$ accounts for the intensity of seasonal growth oscillation, and $W P$ is the time of the year with slowest growth. To compare the VBGF fitted for each sex and beach, an analysis of the residual sum of squares (ARSS) was performed (Chen et al. 1992). The growth index phi prime

$$
\phi^{\prime}=2 \log _{10}\left(L_{\infty}\right)+\log _{10} K
$$

(Pauly \& Munro 1984, Defeo et al. 1992a) was used to measure growth performance.

Longevity was estimated following Algaraja (1984), where the CL containing $99 \%$ of the population $\left(\mathrm{CL}_{99 \%}\right)$ and the largest mode observed in the samples were used to estimate the maximum age $\left(t_{\max }\right)$. A maximum predicted length $\left(\mathrm{CL}_{\exp }\right)$ was also estimated following Gayanilo et al. (1996), who applied extreme value theory to the statistical distribution of the largest organisms observed in the samples to estimate a theoretical largest size that would have been observed in infinitely large and numerous samples. $\mathrm{CL}_{99 \%}$ and $\mathrm{CL}_{\text {exp }}$ are independent of the VBGF fitted in this paper (Gayanilo et al. 1996).

The length (CL)-dry weight $(W$ ) relationship was estimated separately by sex by a power function of the form

$$
W=a \cdot \mathrm{CL}^{b}
$$

where $a$ and $b$ are parameters. An ANCOVA was used to compare the CL- $W$ relationship fitted for each sex between beaches.

The instantaneous rate of natural mortality $(M)$ was calculated by length-converted catch curves (LCCC: Pauly et al. 1995), using the ELEFAN II routine of the FISAT program (Gayanilo et al. 1996). The estimation of $M$ when growth exhibits annual oscillations (i.e., $C>0$ ) was given by

$$
\ln (N)=g-M \cdot t
$$

where $N$ is the number of mole crabs in cohorts 'sliced' by means of successive growth curves, $g$ is the regression intercept, $t$ is the estimated age in each cohort, and $M$, with sign changed, is the unbiased mortality estimate (Pauly et al. 1995). An ANCOVA discriminated by sex was used to compare $M$ between beaches, using age as the covariate. 
Burrowing time was analysed for both mole crab populations, covering the full size range of individuals. It was recorded in situ with a stopwatch to the nearest $0.01 \mathrm{~s}$, as the time in seconds from initiation of digging until the posterior edge of a mole crab become flush with the sand surface (Brown \& Trueman 1996). Burial rates of both mole crab populations were estimated during the same sampling date to avoid the well-known effect of temperature on burrowing rates (Ansell 1983). An ANCOVA was used to compare the length-burrowing time relationship between populations, using length as the covariate. For each mole crab we also calculated the Burrowing Rate Index (BRI: Stanley 1970, see also Vermeij \& Zipser 1986 and Brown \& Trueman 1994)

$$
\mathrm{BRI}=\frac{\sqrt[3]{\text { wet } W}}{\text { burrowing time }}
$$

where wet $W$ is the wet weight $(\mathrm{g})$ and burrowing time is expressed in seconds.

\section{RESULTS}

In order to answer the main question stated in the 'Introduction', we follow up on some predictions of the SEH.

\section{First prediction: abundance is higher at the dissipative beach}

Contrasting with the main SEH prediction, abundance of Emerita brasiliensis did not differ between beaches. Overall mean estimates were higher for the reflective beach, Arachania, than for Barra del Chuy (Fig. 1) for the total population (mean \pm standard error: $1316 \pm 588$ vs $969 \pm 335$ ind. $\mathrm{m}^{-1}$ respectively), and also for adult males (468 \pm 588 vs $261 \pm 100$ ind. $\mathrm{m}^{-1}$ ) and females $\left(585 \pm 225\right.$ vs $571 \pm 194$ ind. $\left.\mathrm{m}^{-1}\right)$. However, the high between-month variability precluded the detection of statistical significance for the total population $\left(t_{1,42}=-0.86 ; \mathrm{p}=0.39\right)$, and for adult males $\left(t_{1,42}=0.17 ; \mathrm{p}=0.86\right)$ and females $\left(t_{1,42}=-1.16 ; \mathrm{p}=0.25\right)$ separately. Paired $t$-tests also showed that total abundance was significantly higher $(p<0.05)$ at Barra del Chuy in only 6 of the 22 months analysed, whereas females and males had significantly higher abundance $(p<0.05)$ than at Arachania in only 8 and $1 \mathrm{mo}$, respec- tively. A higher between-month variability for the reflective beach was observed: abundance ranged from 0 to 11797 ind. $\mathrm{m}^{-1}$ at Arachania and from 0 to 6753 ind. $\mathrm{m}^{-1}$ at Barra del Chuy. A recurrent annual peak occurred in March for Barra del Chuy and April for Arachania during both years.

Ovigerous females were more abundant in the dissipative beach $\left(t_{1,14}=-6.71 ; \mathrm{p} \ll 0.01\right.$, Fig. 2$)$. Reproductive activity occurred between late summer and early autumn in both populations, ovigerous females being almost absent from June to November. The clearest peaks occurred at Barra del Chuy in March 1996 and March 1997, but the latter was part of a 5 mo reproductive season from December to April. Conversely, ovigerous females at Arachania were recorded only in April, indicating a much shorter reproductive season. On the other hand, abundance fluctuations of males with spermatophores did not differ between beaches $\left(t_{1,20}=1.41_{\text {; }}\right.$ $p=0.17$, Fig. 2). They resembled the same reproductive period as ovigerous females, with a main peak in both beaches from January to May, and a secondary one in October-November. Between-month variability was also much higher at Arachania than at Barra del Chuy.

Mean abundance of megalops did not differ between beaches $\left(t_{1,16}=-0.47 ; \mathrm{p}=0.64\right)$. They showed the same

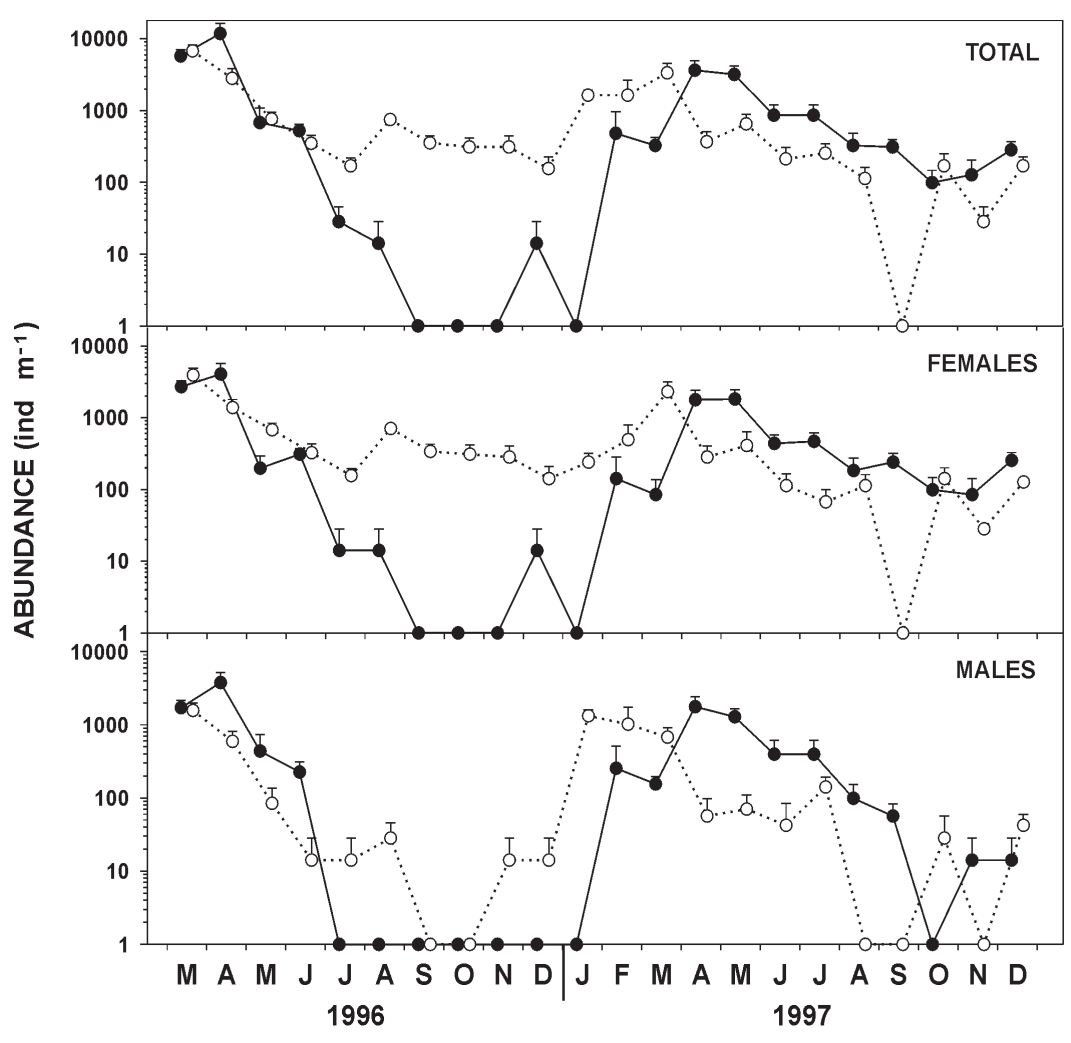

Fig. 1. Emerita brasiliensis. Monthly variations in abundance (ind. $\mathrm{m}^{-1}$ : mean $+\mathrm{SE}$ ) of the total population, females and males in Barra del Chuy $(\cdots \circ \cdots)$ and Arachania (--). Note the logarithm scale 
intra-annual pattern as ovigerous females and males with spermatophores, with an approximated time delay of 1 mo between the peak of massive maturation and recruitment to the beach (Fig. 2). Megalops peaked in March-April 1996 and from February to May 1997 in both beaches. However, they were also abundant from April to July 1997 at Barra del Chuy (i.e., up to 100 ind. $\mathrm{m}^{-1}$ ), suggesting a more extended recruitment period than at the reflective beach.

\section{Second prediction: largest reproduc- tive sizes and higher fecundity are found at the dissipative beach}

Female mole crabs at Barra del Chuy were larger and had higher fecundity at length than those of Arachania. The minimum size (CL) of an ovigerous female was $14 \mathrm{~mm}$ for Barra del Chuy and $17 \mathrm{~mm}$ for Arachania, whereas the maximum was 26 and $23 \mathrm{~mm}$, respectively. The $\mathrm{CL}$ (mean $\pm \mathrm{SD}$ ) of ovigerous females was $20.67 \pm 1.15 \mathrm{~mm}$ for Arachania and $21.23 \pm 1.72 \mathrm{~mm}$ for Barra del Chuy, with an egg production of, respectively, $6961 \pm 2128$ and $8287 \pm 3543$ eggs female ${ }^{-1}$. Hence, the lengthfecundity relationship for Barra del Chuy was significantly higher than for Arachania (ANCOVA $F_{1,88}=$ 4.87; $\mathrm{p}<0.03$ ) (Fig. 3, Table 1). The expected number of eggs $\mathrm{m}^{-1}$, estimated by the product of mean IST estimates of ovigerous females and mean individual fecundity, was more than 5 times higher for Barra del


Arachania (351 203 eggs m$^{-1}$ in April 1997). The opposite trend was observed in males. The minimum CL of a male with spermatophores was $4 \mathrm{~mm}$ for Barra del

Table 1. Emerita brasiliensis. Parameters of the fecundity function (Eq. 2) fitted for Barra del Chuy and Arachania populations by non-linear regression. Results of ANCOVA are also shown

\begin{tabular}{|c|c|c|c|c|}
\hline \multirow{2}{*}{ Parameter } & \multicolumn{2}{|c|}{ Arachania } & \multicolumn{2}{|c|}{ Barra del Chuy } \\
\hline & Mean (SE) & $\mathrm{p}$ & Mean (SE) & $\mathrm{p}$ \\
\hline C & $13.61(31.34)$ & 0.6658 & $0.06(0.11)$ & 0.5850 \\
\hline$d$ & $2.06(0.76)$ & 0.0091 & $3.89(0.56)$ & 0.0001 \\
\hline $\mathrm{r}^{2}$ & 0.13 & 0.0069 & 0.58 & 0.0001 \\
\hline \multicolumn{5}{|c|}{ ANCOVA: $F_{1,89}=4.87 ; \mathrm{p}=0.0298$} \\
\hline
\end{tabular}

Chuy and $5 \mathrm{~mm}$ for Arachania, whereas the maximum was 13 and $12 \mathrm{~mm}$, respectively. The mean CL ( $\pm 1 \mathrm{SD})$ of male with spermatophores was significantly higher (ANOVA $F_{1,93}=21.89 ; \mathrm{p} \ll 0.001$ ) for Arachania $(9.47 \pm$ $1.60 \mathrm{~mm}$ ) than for Barra del Chuy $(7.52 \pm 2.13 \mathrm{~mm})$.

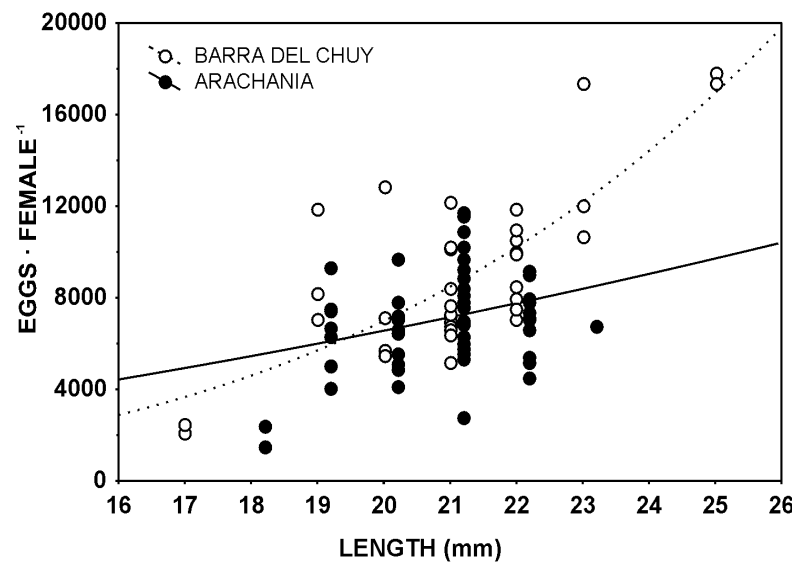

Fig. 3. Emerita brasiliensis. Fecundity function at the reflective (Arachania) and dissipative (Barra del Chuy) beach, fitted by non-linear regression. Statistical results are given in Table 1 
Table 2. Emerita brasiliensis. Growth parameters (annual basis, see Eq. 3) estimated by non-linear least fitting of the von Bertalanffy growth function for Barra del Chuy and Arachania populations discriminated by sex. CL (carapace length) estimates are given in $\mathrm{mm}$

\begin{tabular}{|c|c|c|c|c|c|c|c|c|}
\hline \multirow[t]{3}{*}{ Parameter } & \multicolumn{4}{|c|}{ Females } & \multicolumn{4}{|c|}{ Males } \\
\hline & \multicolumn{2}{|c|}{ Arachania } & \multicolumn{2}{|c|}{ Barra del Chuy } & \multicolumn{2}{|c|}{ Arachania } & \multicolumn{2}{|c|}{ Barra del Chuy } \\
\hline & Mean (SE) & $\mathrm{p}$ & Mean (SE) & $\mathrm{p}$ & Mean (SE) & $\mathrm{p}$ & Mean (SE) & $\mathrm{p}$ \\
\hline$L_{\infty}(\mathrm{mm} \mathrm{CL})$ & $26.98(2.14)$ & 0.0000 & $28.07(2.24)$ & 0.0000 & $14.11(2.02)$ & 0.0009 & $13.31(1.56)$ & 0.0001 \\
\hline$K\left(\mathrm{yr}^{-1}\right)$ & $1.15(0.23)$ & 0.0004 & $1.55(0.38)$ & 0.0017 & $2.43(0.80)$ & 0.0295 & $1.91(0.63)$ & 0.0229 \\
\hline$C$ & $1.00(0.14)$ & 0.0000 & $0.95(0.23)$ & 0.0018 & $1.00(0.00)$ & 0.0000 & $1.00(0.00)$ & 0.0000 \\
\hline$W P$ & $0.54(0.03)$ & 0.0000 & $0.60(0.06)$ & 0.0000 & $0.54(0.06)$ & 0.0004 & $0.46(0.04)$ & 0.0003 \\
\hline$t_{0}(\mathrm{yr})$ & $-0.04(0.02)$ & 0.0400 & -0.02 & 0.4846 & $-0.04(0.02)$ & 0.0898 & $-0.07(0.03)$ & 0.0485 \\
\hline $\mathrm{r}^{2}$ & 0.98 & 0.0000 & 0.97 & 0.0000 & 0.96 & 0.0000 & 0.94 & 0.0000 \\
\hline$\phi^{\prime}$ & \multicolumn{2}{|c|}{2.92} & \multicolumn{2}{|c|}{3.29} & \multicolumn{2}{|c|}{2.68} & \multicolumn{2}{|c|}{2.53} \\
\hline Largest CL & \multicolumn{2}{|c|}{24} & \multicolumn{2}{|c|}{26} & \multicolumn{2}{|c|}{14} & \multicolumn{2}{|c|}{14} \\
\hline $\mathrm{CL}_{99 \%}$ & \multicolumn{2}{|c|}{17.55} & \multicolumn{2}{|c|}{24.87} & \multicolumn{2}{|c|}{10.60} & \multicolumn{2}{|c|}{11.51} \\
\hline $\mathrm{CL}_{\exp } \pm 95 \mathrm{CI}$ & \multicolumn{2}{|c|}{$24.20(2.78)$} & \multicolumn{2}{|c|}{28.31 (1.39) } & \multicolumn{2}{|c|}{$14.60(1.04)$} & \multicolumn{2}{|c|}{$15.49(1.79)$} \\
\hline Life span (mo) & \multicolumn{2}{|c|}{16} & \multicolumn{2}{|c|}{14} & \multicolumn{2}{|c|}{11} & \multicolumn{2}{|c|}{11} \\
\hline
\end{tabular}

\section{Third prediction: growth rates are higher and sizes largest at the dissipative beach}

Mole crab females at Barra del Chuy grew significantly larger than at Arachania (Fig. 4, Table 2). This was corroborated by ARSS analysis $\left(F_{3,26}=21.26\right.$; $\mathrm{p} \ll$ $0.001)$ and a higher $\phi$ value. The non-linear fitting of the VBGF explained more than $97 \%$ of the variance in both cases, and growth parameters were significant $\left(\mathrm{p}<0.05\right.$ : Table 2), except $t_{0}$ at Barra del Chuy. Intense intra-annual growth oscillations $(C=1)$ and a consistent minimal growth in austral winter, i.e., June for Arachania $(W P=0.54)$ and July for Barra del Chuy (WP $=0.60$ ) were detected (Fig. 4). The minimum size was 2 and $3 \mathrm{~mm}$ for Arachania and Barra del Chuy, respectively, and the maximum was 24 and $26 \mathrm{~mm}$. CL99\% was larger for Barra del Chuy (24.87 mm) than for Aracha- nia $(17.55 \mathrm{~mm})$. Longevity $t_{\max }$ corresponding to these estimates and to the largest mode observed in the samples (see Fig. 4) was close to 16 and 14 mo, respectively. In agreement with these trends, $\mathrm{CL}_{\exp }$ values (mean $\pm 95 \% \mathrm{CI}$ ) estimated by extreme value theory were higher for Barra del Chuy $(28.31 \pm 1.39 \mathrm{~mm})$ than for Arachania $(24.20 \pm 2.78 \mathrm{~mm})$.

Contrary to the predictions of the $\mathrm{SEH}$, growth rates of male mole crabs at Arachania were significantly higher than at the dissipative Barra del Chuy (ARSS analysis: $F_{3,15}=10.02 ; \mathrm{p}<0.0007$ ). The VBGF explained more than $94 \%$ in both cases and, with the exception of $t_{0}$, growth parameters were significant $(\mathrm{p}<0.05$ : Table 2). Intra-annual growth oscillations showed minimal growth in June for Arachania $(W P=0.54)$ and May-June for Barra del Chuy (WP $=0.46)$, increasing markedly in austral spring (Fig. 4). The minimum
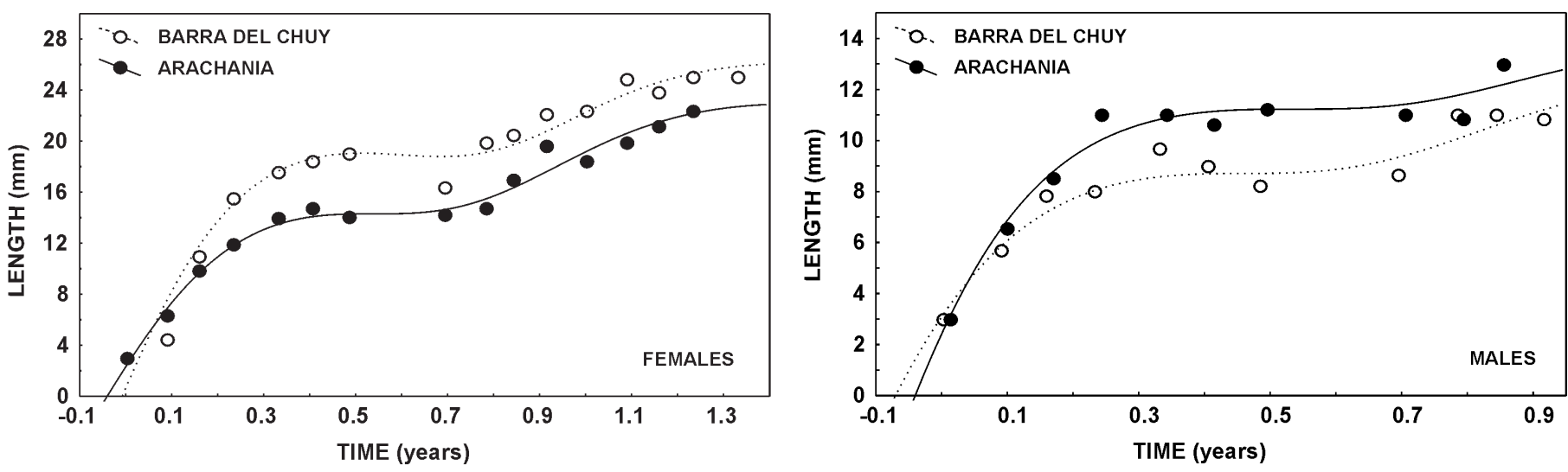

Fig. 4. Emerita brasiliensis. Seasonal growth curves fitted for Arachania and Barra del Chuy populations. Circles represent the modal lengths determined by maximum likelihood at each age. Statistical results are detailed in Table 2 
Table 3. Emerita brasiliensis. Parameters (mean \pm SE) of the length-weight relationship (non-linear fitting, see Eq. 4) for Barra del Chuy and Arachania populations, discriminated by sex. Regressions and parameter estimates were highly significant in all cases $(\mathrm{p}<0.0001)$. ANCOVA results are also shown

\begin{tabular}{|lcccc|}
\hline \multirow{2}{*}{ Parameter } & \multicolumn{2}{c}{ Females } & \multicolumn{2}{c|}{ Males } \\
& Arachania & Barra del Chuy & Arachania & Barra del Chuy \\
\hline$a$ & $0.000018(0.000002)$ & $0.000024(0.000002)$ & $0.000080(0.000017)$ & $0.000037(0.000007)$ \\
$b$ & $3.40(0.05)$ & $3.32(0.05)$ & $2.77(0.09)$ & $3.14(0.11)$ \\
$\mathrm{r}^{2}$ & 0.91 & 0.90 & 0.75 & 0.86 \\
ANCOVA & \multicolumn{2}{c}{$F_{1,156}=32.43 ; \mathrm{p} \ll 0.00001$} & $F_{1,747}=0.02 ; \mathrm{p}=0.897$ \\
\hline
\end{tabular}

observed CL was $3 \mathrm{~mm}$ and the maximum was $14 \mathrm{~mm}$ for both beaches. $\mathrm{CL}_{99 \%}$ values were $11.51 \mathrm{~mm}$ for Barra del Chuy and $10.60 \mathrm{~mm}$ for Arachania. Longevity corresponding to these estimates, and to the largest observed mode, was close to 11 mo. $\mathrm{CL}_{\exp }$ values were $15.49 \pm 1.79 \mathrm{~mm}$ for Barra del Chuy and $14.60 \pm 1.04 \mathrm{~mm}$ for Arachania.

The dry weight of females at Barra del Chuy was higher than at Arachania, and thus the corresponding length-dry weight relationship differed significantly between beaches (ANCOVA $F_{1,1156}=32.43$; $\mathrm{p} \ll 0.01$ ). On the contrary, male weight-at-size did not differ between beaches (ANCOVA $F_{1,747}=0.02 ; \mathrm{p}=0.90$ ) (Fig. 5, Table 3).

\section{Fourth prediction: mortality is lower at the dissipative beach}

Comparison of LCCC showed that natural mortality $M$ was significantly higher for females at the reflective beach (ANCOVA $F_{1,17}=52.36$; $\mathrm{p} \ll 0.001$ ), with mean $( \pm \mathrm{SE})$ values of $4.56 \pm 0.57 \mathrm{yr}^{-1}$ for Arachania and $3.43 \pm 0.23 \mathrm{yr}^{-1}$ for Barra del Chuy. Contrasting with the predictions of the $\mathrm{SEH}$, mortality of male mole crabs was significantly higher at the dissipative beach $\left(\right.$ ANCOVA $\left.F_{1,10}=10.20 ; \mathrm{p}<0.01\right)$, with values of $3.41 \pm$ 0.64 and $4.15 \pm 1.29 \mathrm{yr}^{-1}$ for Arachania and Barra del Chuy, respectively (Fig. 6, Table 4).
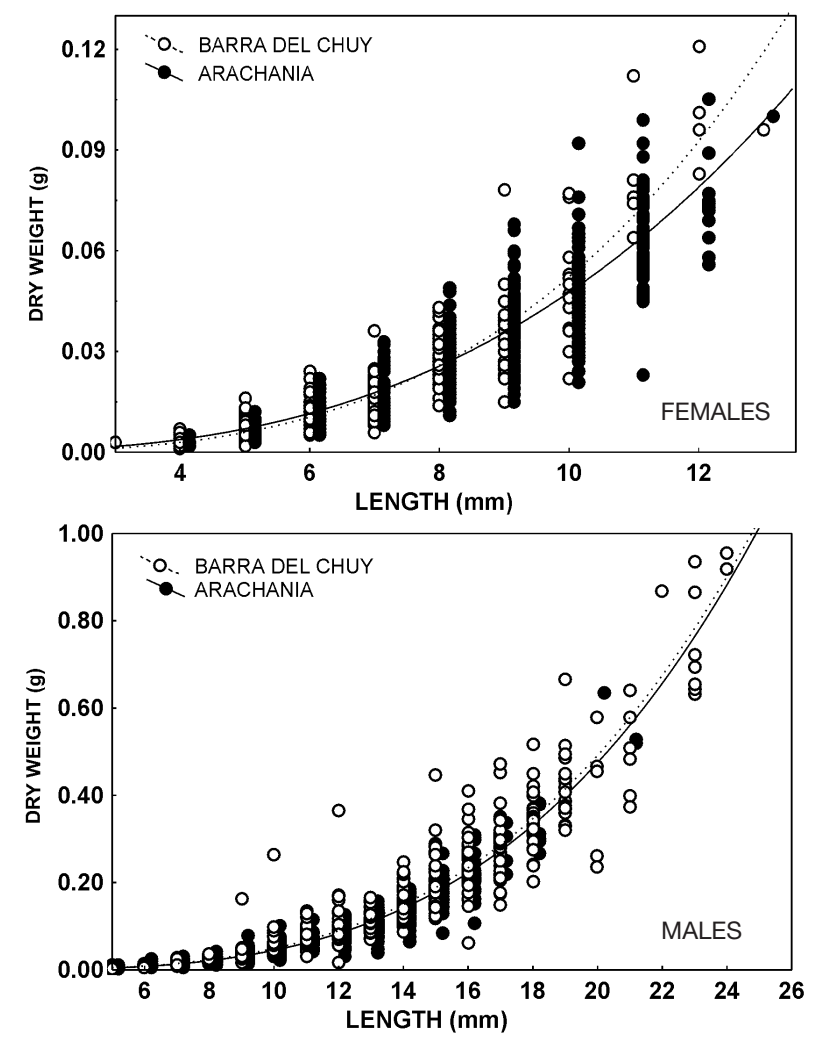

Fig. 5. Emerita brasiliensis. Length-dry weight relationship fitted by sex for Arachania and Barra del Chuy populations. Statistical results are detailed in Table 3

Table 4. Emerita brasiliensis. Mortality estimates ( $M$, see Eq. 5) and associated statistics derived from the length-converted catch curves fitted for Barra del Chuy and Arachania populations. ANCOVA results are also shown

\begin{tabular}{|c|c|c|c|c|c|c|c|c|}
\hline \multirow[t]{3}{*}{ Parameter } & \multicolumn{4}{|c|}{ Females } & \multicolumn{4}{|c|}{ Males } \\
\hline & \multicolumn{2}{|c|}{ Arachania } & \multicolumn{2}{|c|}{ Barra del Chuy } & \multicolumn{2}{|c|}{ Arachania } & \multicolumn{2}{|c|}{ Barra del Chuy } \\
\hline & Mean (SE) & $\mathrm{p}$ & Mean (SE) & $\mathrm{p}$ & Mean (SE) & $\mathrm{p}$ & Mean (SE) & $\mathrm{p}$ \\
\hline$g$ & $6.94(0.63)$ & 0.0000 & $9.08(0.42)$ & 0.0000 & $6.95(0.66)$ & 0.0000 & $9.52(1.50)$ & 0.0079 \\
\hline$M$ & $4.56(0.57)$ & 0.0000 & $3.43(0.23)$ & 0.0000 & $3.41(0.64)$ & 0.0018 & $4.15(1.29)$ & 0.0486 \\
\hline \multirow[t]{2}{*}{$\mathrm{r}^{2}$} & 0.88 & 0.0000 & 0.97 & 0.0000 & 0.82 & 0.0018 & 0.77 & 0.0486 \\
\hline & \multicolumn{4}{|c|}{ ANCOVA $F_{1,17}=52.36 ; \mathrm{p} \ll 0.001$} & \multicolumn{4}{|c|}{ ANCOVA $F_{1,10}=10.20 ; \mathrm{p}<0.01$} \\
\hline
\end{tabular}



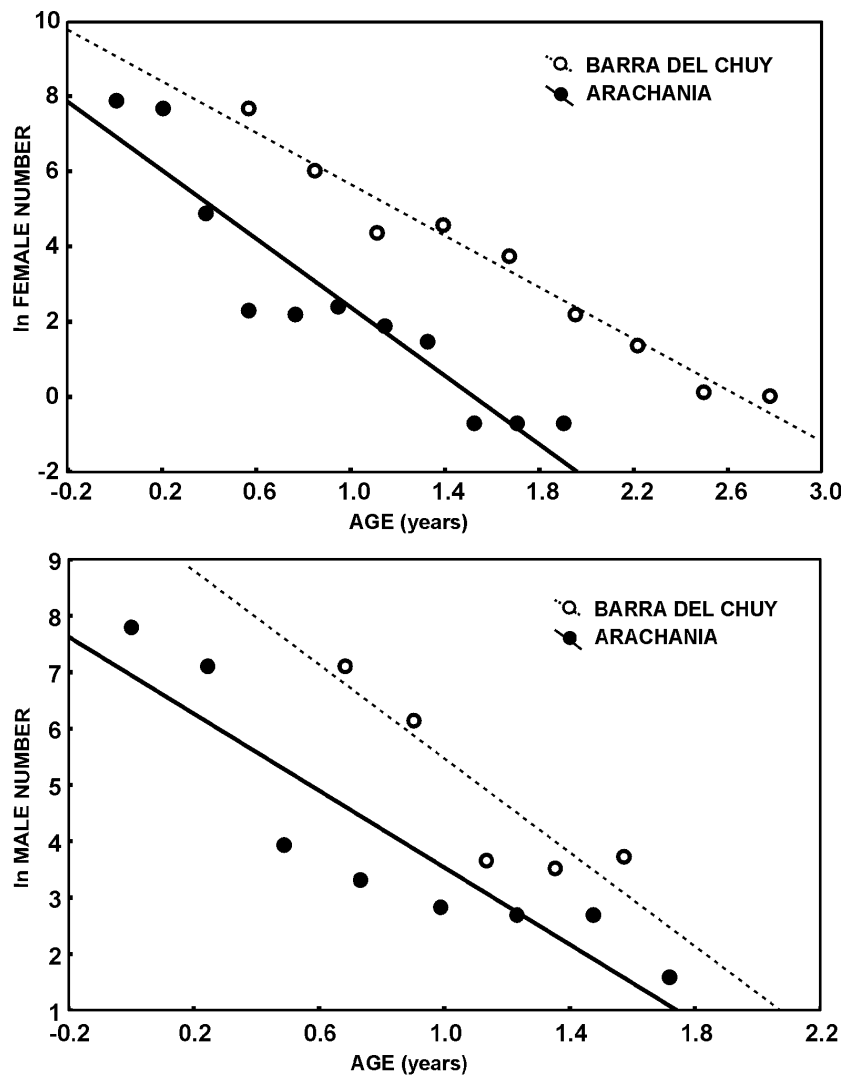

Fig. 6. Emerita brasiliensis. Length-converted catch curves fitted by sex for Arachania and Barra del Chuy populations. Statistical results are detailed in Table 4

\section{Fifth prediction: burrowing rates are lower at the dissipative beach}

The length-burrowing time relationship was significant in both cases (Fig. 7, Table 5); mole crabs at the reflective beach burrowed faster than those at the dissipative beach (ANCOVA $F_{1,140}=39.89 ; \mathrm{p} \ll 0.01$ ). BRI decreased significantly with increasing size in both populations (Fig. 7, Table 5), with smaller individuals burrowing faster than large ones. BRI for mole crabs at the reflective beach ranged from 0.71 to 2.67 and from 0.56 to 2.46 at the dissipative beach. ANCOVA analysis showed that BRI for the reflective beach population was significantly higher $\left(F_{1,140}=47.40 ; \mathrm{p} \ll 0.01\right)$.

\section{DISCUSSION}

\section{Abundance}

Our results, based on 22 consecutive months, showed that the major prediction of the SEH does not hold for the mole crab. An absence of statistical differ- ence in abundance between the dissipative and reflective beach was found for the total population, for males with and without spermatophores, and for females and megalops separately. Only the higher abundance of ovigerous females at the dissipative Barra del Chuy was in accordance to the predictions of the SEH. The lower variability between months at the dissipative beach, where there were fewer cases of absence and considerably higher abundance in the winter period, suggests that the reflective beach is a harsher environment in winter and leads to higher month-to-month variations in population size.

This is not the first example of patterns of abundance not increasing from reflective to dissipative conditions. Many species that co-occur in sandy beaches with contrasting morphodynamics in Uruguayan coasts, e.g., the cirolanid isopod Excirolana braziliensis (Defeo et al. 1997), the sandhopper Pseudorchestoidea brasiliensis (Gómez \& Defeo 1999) and the wedge clam Donax hanleyanus (Defeo unpubl.), showed increasing abundance from dissipative to reflective conditions. Veloso \& Cardoso (1999) also characterised Emerita brasiliensis as a typical and abundant species in the midlit-
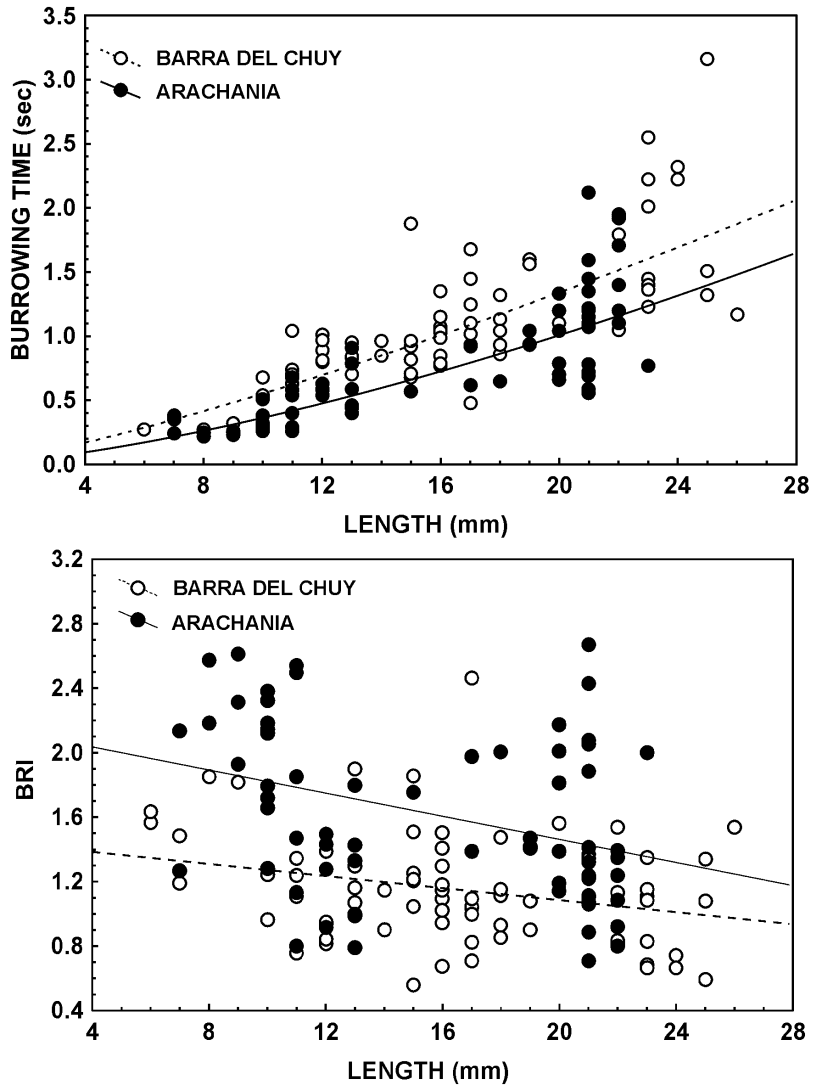

Fig. 7. Emerita brasiliensis. Burrowing time and BRI (Burrowing Rate Index) as a function of CL for Arachania and Barra del Chuy populations. Statistical results are detailed in Table 5 
Table 5. Emerita brasiliensis. Parameters (mean \pm SE) of the linearised length-burrowing time, and length-BRI (Burrowing Rate Index) relationships for Barra del Chuy and Arachania populations. ${ }^{* * *} p \ll 0.001,{ }^{* *} p<0.01$ and ${ }^{*} p<0.05$ for the regressions and parameter estimates. ANCOVA results (logtransformed data) are also shown

\begin{tabular}{|lcc|}
\hline Parameters & Arachania & Barra del Chuy \\
\hline Length - burrowing time & \\
$\ln a$ & $-1.9071(0.1234)^{* * *}$ & $-1.5384(0.1122)^{* * *}$ \\
$b$ & $1.4678(0.1045)^{* * *}$ & $1.2802(0.0932)^{* * *}$ \\
$\mathrm{r}^{2}$ & $0.76^{* * *}$ & $0.72^{* * *}$ \\
ANCOVA $F_{1,140}=47.40 ; \mathrm{p} \ll 0.00001$ & \\
Length - BRI & $2.1792(0.1957)^{* * *}$ & $1.4592(0.1307)^{* * *}$ \\
$a$ & $-0.0358(0.0118)^{* *}$ & $-0.0187(0.0076)^{*}$ \\
$b$ & $0.11^{* *}$ & $0.06^{*}$ \\
$\mathrm{r}^{2}$ & \\
ANCOVA $F_{1,140}=37.72 ; \mathrm{p} \ll 0.00001$ & \\
\hline
\end{tabular}

toral of semi-exposed reflective beaches (grain size = $0.360 \mathrm{~mm}$ ) of the State of Rio de Janeiro, Brazil $\left(22^{\circ} 57^{\prime} \mathrm{S}\right)$. However, the species co-occur in high abundance at the dissipative (Gianuca 1983) and intermediate-toreflective beaches (Calliari et al. 1996) of Southern Brazil $\left(31^{\circ} \mathrm{S}\right)$. Dugan \& Hubbard (1996), sampling 12 intermediate-to-dissipative beaches with grain size between 0.180 and $0.314 \mathrm{~mm}$, well below that documented for Arachania $(0.560 \mathrm{~mm})$, also showed that abundance, biomass, and life history characteristics of Emerita analoga of the California coast were relatively independent of beach morphodynamics.

\section{Reproduction, growth and mortality}

Reproductive aspects of female Emerita brasiliensis strongly supported SEH predictions. Abundance of ovigerous females, fecundity and somatic weight were significantly higher at the dissipative beach. Larger mature females at Barra del Chuy, together with higher fecundity and individual weight, explain the higher reproductive output (eggs $\mathrm{m}^{-1}$ ). These higher biological indicators for the dissipative beach could be attributed to a higher amount of food availability, provided by the beach itself and by a surf zone extremely rich in surf phytoplankton (Defeo \& Scarabino 1990). Female mole crabs at the dissipative beach would achieve larger sizes, $\mathrm{CL}_{99 \%}$ and weights by delaying maturity and thus they should be able to allocate more resources to maintenance, reproduction and somatic growth than in the reflective beach with reduced food availability. These trends were accompanied by lower mortality, which was also in agreement with SEH predictions. High mortality rates of female crabs at the reflective beach should mean that eggs are produced only by younger females, affecting total reproductive output (Wenner 1988). Lercari \& Defeo (1999) also found an exponential decrease in the size at maturity and reproductive output of $E$. brasiliensis at sites with food scarcity, where growth in length and weight, survival and fecundity were lower.

Higher abundance of ovigerous females, as well as individual fecundity, weight, size and reproductive output, constitute consistent and recurrent features in sandy beach populations that give strong support to the SEH. Dugan et al. (1994) also reported the largest sizes of ovigerous Emerita analoga sand crabs at dissipative beaches with major amount of food availability. Moreover, Gómez \& Defeo (1999) found higher growth in weight, individual fecundity, and average size at maturity of the sandhopper Pseudorchestoidea brasiliensis at a dissipative beach, concluding that this trend remains valid for species living somewhat outside the swash climate.

The number of reproductive and recruitment events, which occurred between late summer and early autumn, did not differ between populations. However, reproductive males, females, and megalops at the reflective beach presented stronger abundance peaks, much higher intra-annual variability and narrower reproductive and recruitment seasons than in the dissipative beach. This synchronicity should be directed to override the effect of widely fluctuating and harsh reflective environments such as Arachania. This phenomenon can be explained by intra-specific cooperation or density-induced positive feedback (sensu Berryman 1997), also called 'Allee effect', which in Emerita brasiliensis should be seen as an adaptation to increase the probability of copulation with the low and infrequent reproductive females. This phenomenon has been suggested as a major cause of population instability (Berryman 1997) and could explain the high abundance variability on reflective beach populations (Gómez \& Defeo 1999). Another explanatory hypothesis could be that reproductive females on dissipative beaches seed reflective beaches. Indeed, like most suspension feeders on sandy beaches, the mole crab is a metapopulation with planktonic larvae and an unknown degree of connectance between metapopulation components (Defeo 1996). This hypothesis must be subject to further testing.

Abundance of males with spermatophores did not differ between beaches. Males also attained significantly higher growth rates and weight at size, as well as lower mortality at the reflective beach. These interrelated trends clearly did not follow SEH predictions and should be seen in the context of positive densitydependent feedback mentioned above. Higher growth rates should lead to a precocious sexual maturity and early spawning at smaller sizes at Arachania, which should be advantageous to the mole crabs to increase 
reproductive output and fitness in the harsh surf zone of high energy reflective beaches (Veloso \& Cardoso 1999). On the other hand, lower growth rhythms in males at Barra del Chuy could be explained by alternative mechanisms to environmental forcing. Indeed, Lercari \& Defeo (1999) recently documented spatial density-dependent growth in male mole crabs in $22 \mathrm{~km}$ of beach sampled, through an inverse correlation between male sizes and total abundance of Emerita brasiliensis. Lercari (2000) also suggested an inverse correlation between female abundance and male sizes. Gravid females need to allocate more resources to both reproduction and somatic reserves. This, together with a greater filtering capacity and individual growth rates, might limit food availability and accessibility to smaller males, considered as subordinate intra-specific competitors for food (Lercari \& Defeo 1999). The above 'rapid density-induced negative feedback' (Berryman 1997) given by asymmetric intra-specific competition (e.g., recruits, adults) is now considered a critical regulating process in sandy beach populations (Defeo 1993, 1998, Defeo \& de Alava 1995). This result is particularly meaningful for sandy beach population ecology, where the dominant paradigm is based on the concept of population regulation by physical factors.

Variations in recruitment abundance cannot be explained by variations in fecundity and abundance of gravid females. High mortality rates during the planktonic larval stage might explain why recruitment did not differ between beaches in spite of high fecundity values and reproductive output in the dissipative beach. Dugan \& Hubbard (1996) showed that mean individual size and mean ovigerous size of Emerita analoga were negatively correlated with megalopa abundance, suggesting that intra-specific interactions can influence populations of this mole crab.

Size is one of the most important biological attributes of organisms, and its variations together with growth rates are critical for disproving a hypothesis. The prediction that larger sizes occur in benign, dissipative environments was in agreement with estimates of $\mathrm{CL}_{99 \%}$, which take into account the overall population structure, and also $\mathrm{CL}_{\text {exp }}$ derived from extreme theory. These independent estimates of the VBGM gave strong support for the SEH. However, Jaramillo \& McLachlan (1993) showed that the isopod Excirolana braziliensis and the sand crab Emerita analoga had no clear patterns in the relationship between body size and the physical beach features of Chile. Defeo et al. (1997) documented an increase in individual size for the cirolanid isopod $E$. braziliensis at reflective beaches. Dugan \& Hubbard (1996) and Gómez \& Defeo (1999) found, respectively, that size structure of E. analoga and Pseudorchestoidea brasiliensis was not correlated with beach morphodynamics. These contradictory trends imply that independent re- sponses of individual species to beach morphodynamics might explain variations in life history traits, demography and population dynamics. This suggests a locally adjusted phenotype (see also Gómez \& Defeo 1999).

Natural mortality of female mole crabs was higher at Arachania and thus gave support for the SEH. This should explain the clear absence of ovigerous females almost throughout the study period. The higher mortality rates of females at the reflective beach could be explained by a synergistic action of food scarcity, a critical factor for ovigerous females, and environmental harshness. On the other hand, male natural mortality did not support the SEH either. High rates of male mortality at the dissipative beach could be explained by size-dependent predation effects by birds, gastropods, crabs, fishes and insects, which are by far more abundant at dissipative beaches (Griffiths et al. 1983, Brown \& McLachlan 1990, Colombini \& Chelazzi 1996). Predation could act as the main selection pressure determining body size, and thus higher growth rates of females, postulated as dominant intra-specific competitors, should be directed to diminish predation risks. An active selection of the site by adult females (see below) could also be invoked to decrease predation and desiccation risks.

Unpredictable, strong and dramatic short-term increases in tide ranges (i.e., up to the sand dunes) generated by storm surges and barometric tides could be another source of size-dependent mortality in males, because of differential zonation patterns between juveniles and males with respect to adult females. Whereas small organisms (juveniles and males) remain in the swash zone close to the substratum surface and are more dependent on passive transport by waves, adult females of large body size regulate their position on the beach by an active process involving high mobility and complex behavioural adaptations to fast burrowing (Trueman 1970, Brazeiro \& Defeo 1996, Giménez \& Yannicelli 1997). These animals are found at lower fringes of the intertidal or even in the subtidal, at $30 \mathrm{~cm}$ deep. Thus, they are not exposed at the same degree as smaller males (Lercari \& Defeo 1999, Veloso $\&$ Cardoso 1999). These differential zonation patterns have been described for the sympatric yellow clam Mesodesma mactroides and wedge clam Donax hanleyanus (Defeo et al. 1986, de Alava 1993, Defeo 1993). Strong barometric tides, storm surges, and winddriven surf off the ocean strand smaller organisms in the upperlittoral and usually determine common mass mortalities of recruits and juveniles of the abovementioned species (de Alava 1993, Defeo 1993). Mass mortalities of males at a dissipative beach probably occur at a higher frequency than at a reflective beach, where wave intrusion is mitigated by the steep slope on the lower shore (Gómez \& Defeo 1999). 


\section{Burrowing}

Mole crabs burrowed significantly faster at the reflective beach. Also, the clear relationship between $\mathrm{BRI}$ and beach type was in agreement with SEH predictions (McLachlan et al. 1995). Decreasing sand particle size and sediment penetrability limit burrowing ability of Emerita brasiliensis at the dissipative beach, whereas at the harshest reflective beach with smaller swash periods, the mole crab burrows very quickly. BRI was also dependent of length, with smaller individuals burrowing faster than larger ones. This should also explain the lower sizes observed and predicted by extreme theory for the reflective beach, which could be invoked as a long-term adaptation to colonize the harshest beaches (McLachlan et al. 1995).

\section{Towards a theoretical model on sandy beach population dynamics}

The results obtained herein strongly support the view that beach morphodynamics might not be considered the primary factor affecting the abundance, population dynamics and life history traits of macrofauna species. Population level responses to beach characteristics differ markedly from community level responses, and thus macroscale community patterns could not necessarily characterize life history and demographic variations in individual macrofauna species. This might be especially true in species like Emerita brasiliensis, with great plasticity in life history traits. In this context, individuals from populations inhabiting reflective beaches are able to adapt to the harsh conditions by plastic-mediated responses. The higher or even similar abundance in a priori adverse scenarios, or under contrasting environmental conditions and on a biogeographic scale, should mean a locally adjusted phenotype in reproduction, fecundity and growth in order to optimize fitness (Stearns \& Koella 1986, Scapini et al. 1995). This high phenotypic plasticity enables the species to adapt to both short- and long-term stress (Brown 1996, Soares et al. 1999). The fact that dissimilar responses of populations could also result from locally adjusted genotypes or a combination of plastic and genetic responses should not be discarded. We are continuing this work by comparing mole crab populations and size-specific responses along a continuum of morphodynamic ranges on a macroscale (100s of $\mathrm{km}$ ).

Although it is known that factors such as wave exposure, intertidal slope and grain size play an important role, we showed that physical factors do not have exclusivity in the regulation of sandy beach populations. Instead, we think that sandy beach populations are controlled by the interaction between density- independent and density-dependent factors (Defeo 1993, 1996, 1998, Defeo et al. 1997, Brazeiro \& Defeo 1999, Gómez \& Defeo 1999, Lercari \& Defeo 1999). Lima et al. (2000) recently gave strong support to this hypothesis, by successfully modelling long-term fluctuations of the yellow clam population in Uruguayan coasts. They suggested that population fluctuations are produced by the intertwined forces of exogenous factors, environmental disturbances and density-dependent factors operating together. The combination between stochasticity in reproductive rates and asymmetric inter-cohort interactions (density-dependent recruitment and density-dependent survival rates) could be suggested as key processes generating large variability in sandy beach populations.

Acknowledgements. Dr A. McLachlan and 3 anonymous referees provided valuable suggestions on the final manuscript. We wish to express our gratitude to the 'Benthic Ecology Group' from UNDECIMAR and INAPE for field and laboratory assistance. Financial support from INAPE, CONICYT (Project Nos. 1018 and 4034) and PEDECIBA is acknowledged.

\section{LITERATURE CITED}

Algaraja K (1984) Simple methods for estimation of parameters for assessing exploited fish stocks. Indian J Fish 31: 177-208

Ansell AD (1983) The biology of the genus Donax. In: McLachlan A, Erasmus T (eds) Sandy beaches as ecosystems. W Junk, The Hague, p 607-635

Berryman AA (1997) On the principles of population dynamics and theoretical models. Am Entomol 43:147-151

Borzone CA, Souza JRB, Soares AG (1996) Morphodynamic influence on the structure of inter and subtidal macrofaunal communities of subtropical sandy beaches. Rev Chil Hist Nat 69:565-577

Brazeiro A, Defeo O (1996) Macroinfauna zonation in microtidal sandy beaches: is it possible to identify patterns in such variable environments? Estuar Coast Shelf Sci 42:523-536

Brazeiro A, Defeo O (1999) Effects of harvesting and densitydependence on the demography of sandy beach populations: the yellow clam Mesodesma mactroides of Uruguay. Mar Ecol Prog Ser 182:127-135

Brown AC (1996) Behavioural plasticity as a key factor in the survival and evolution of the macrofauna on exposed sandy beaches. Rev Chil Hist Nat 69:469-474

Brown AC, McLachlan A (1990) Ecology of sandy shores. Elsevier, Amsterdam

Brown AC, Trueman ER (1994) The burrowing rate index. J Molluscan Stud 60:354-355

Brown AC, Trueman ER (1996) Burrowing behaviour and cost in the sandy-beach oniscid isopod Tylos granulatus Krauss, 1843. Crustaceana 69:425-437

Calliari LJ, Klein AHF, Barros FCR (1996) Beach differentiation along the Rio Grande do Sul coastline (southern Brazil). Rev Chil Hist Nat 69:485-493

Chen Y, Jackson DA, Harvey HH (1992) A comparison of von Bertalanffy and polynomial functions in modelling fish growth data. Can J Fish Aquat Sci 49:1228-1235

Colombini I, Chelazzi L (1996) Environmental factors influencing the surface activity of Eurynebia complanata 
(Coleoptera, Carabidae). Rev Chil Hist Nat 69:511-537

de Alava A (1993) Interdependencias ecológicas entre dos bivalvos simpátricos en una playa arenosa de la costa atlántica Uruguaya. MSc thesis, CINVESTAV-IPN, Mérida

Defeo O (1993) The effect of spatial scales in population dynamics and modelling of sedentary fisheries: the yellow clam Mesodesma mactroides of an Uruguayan exposed sandy beach. PhD thesis, CINVESTAV-IPN, Mérida

Defeo O (1996) Recruitment variability in sandy beach macroinfauna: much to learn yet. Rev Chil Hist Nat 69:615-630

Defeo O (1998) Testing hypotheses on recruitment, growth and mortality in exploited bivalves: an experimental perspective. Can Spec Publ Fish Aquat Sci 125:257-264

Defeo O, de Alava A (1995) Effects of human activities on long-term trends in sandy beach populations: the wedge clam Donax hanleyanus in Uruguay. Mar Ecol Prog Ser 123:73-82

Defeo O, Scarabino V (1990) Ecological significance of a possible deposit-feeding strategy in Mesodesma mactroides (Deshayes, 1854) (Mollusca: Pelecypoda). Atlántica 12:55-65

Defeo O, Layerle C, Masello A (1986) Spatial and temporal structure of the yellow clam Mesodesma mactroides (Deshayes, 1854) in Uruguay. Medio Ambiente (Chile) 8:48-57

Defeo O, Arreguín-Sánchez F, Sánchez J (1992a) Growth study of the yellow clam Mesodesma mactroides: a comparative analysis of three length-based methods. Sci Mar 56:53-59

Defeo O, Jaramillo E, Lyonnet A (1992b) Community structure and intertidal zonation of the macroinfauna in the Atlantic coast of Uruguay. J Coastal Res 8:830-839

Defeo O, Brazeiro A, de Alava A, Riestra G (1997) Is sandy beach macroinfauna only physically controlled? Role of substrate and competition in isopods. Estuar Coast Shelf Sci 45:453-462

Díaz H, Conde JE, Bevilacqua M (1983) A volumetric method for estimating fecundity in Decapoda. Mar Ecol Prog Ser 10:203-206

Dugan JE, Hubbard DM (1996) Local variation in populations of the sand crab Emerita analoga on sandy beaches in southern California. Rev Chil Hist Nat 69:579-588

Dugan JE, Hubbard DM, Wenner AM (1994) Geographic variation in life history of the sand crab, Emerita analoga (Stimpson) on the California coast: relationships to environmental variables. J Exp Mar Biol Ecol 181:255-278

Efford IE (1976) Distribution of the sand crab in the genus Emerita (Decapoda, Hippidae). Crustaceana 30:169-183

Gayanilo FC Jr, Sparre P, Pauly D (1996) The FAO-ICLARM stock assessment tools (FISAT) user's guide. FAO Computerized Information Series (Fisheries) No 8, Rome

Gianuca NM (1983) A preliminary account of the ecology of sandy beaches in southern Brazil. In: McLachlan A, Erasmus T (eds) Sandy beaches as ecosystems. W Junk, The Hague, p 413-419

Giménez L, Yannicelli B (1997) Variability of zonation patterns in temperate microtidal Uruguayan beaches with different morphodynamic types. Mar Ecol Prog Ser 160:197-207

Gómez J, Defeo O (1999) Life history of the sandhopper Pseudorchestoidea brasiliensis (Amphipoda) in sandy beaches with contrasting morphodynamics. Mar Ecol Prog Ser 182:209-220

Griffiths CL, Stenton-Dozey JME, Koop K (1983) Kelp wrack and energy flow through a sandy beach. In: McLachlan A, Erasmus T (eds) Sandy beaches as ecosystems. W Junk, The Hague, p 547-556

Jaramillo E, McLachlan A (1993) Community and population responses of the macroinfauna to physical factors over a range of exposed sandy beaches in south-central Chile. Estuar Coast Shelf Sci 37:615-624

Editorial responsibility: Otto Kinne (Editor), Oldendorf/Luhe, Germany
Lercari D (2000) Efectos de la descarga de agua dulce en poblaciones de playas arenosas: el 'tatucito' Emerita brasiliensis en Uruguay. MSc thesis, PEDECIBA, Facultad de Ciencias, Montevideo

Lercari D, Defeo O (1999) Effects of freshwater discharge in sandy beach populations: the mole crab Emerita brasiliensis in Uruguay. Estuar Coast Shelf Sci 49:457-468

Lima M, Brazeiro A, Defeo O (2000) Population dynamics of the yellow clam Mesodesma mactroides: recruitment variability, density-dependence and stochastic processes. Mar Ecol Prog Ser 207:97-108

McLachlan A (1990) Dissipative beaches and macrofauna communities on exposed intertidal sands. J Coastal Res 6: $57-71$

McLachlan A, Jaramillo E, Donn TE, Wessels F (1993) Sand beach macrofauna communities: a geographical comparison. J Coastal Res 15:27-38

McLachlan A, Jaramillo E, Defeo O, Dugan J, de Ruyck A, Coetzee P (1995) Adaptations of bivalves to different beach types. J Exp Mar Biol Ecol 187:147-160

McLachlan A, Dugan JE, Defeo O, Ansell AD, Hubbard DM, Jaramillo E, Penchaszadeh P (1996) Beach clam fisheries. Oceanogr Mar Biol Annu Rev 34:163-232

Pauly D, Munro JL (1984) Once more on the comparison of growth in fish and invertebrates. Fishbyte 2(1):21

Pauly D, Moreau J, Abad N (1995) Comparison of age structure and length-converted catch curves of brown trout Salmo trutta in two French rivers. Fish Res 22:197-204

Peluffo E (1998) Distribución espacio-temporal, estructura poblacional y reproducción del tatucito Emerita brasiliensis (Decapoda, Hippidae) en las playas de Cabo Polonio, Rocha, Uruguay. MSc thesis, PEDECIBA, Facultad de Ciencias, Montevideo

Ricciardi A, Bourget E (1999) Global patterns of macroinvertebrate biomass in marine intertidal communities. Mar Ecol Prog Ser 185:21-35

Scapini F, Buiatti M, De Matthaeis E, Mattoccia M (1995) Orientation behaviour and heterozygosity of sandhopper populations in relation to stability of beach environments. J Evol Biol 8:43-52

Short AD (1996) The role of wave height, period, slope, tide range and embaymentisation in beach classifications: a review. Rev Chil Hist Nat 69:589-604

Soares AG, Scapini F, Brown AC, McLachlan A (1999) Phenotypic plasticity, genetic similarity and evolutionary inertia in changing environments. J Molluscan Stud 65:136-139

Stanley SM (1970) Relation of shell form to life habits of the Bivalvia (Mollusca). Geol Soc Am Mem 125:1-296

Stearns SC, Koella JC (1986) The evolution of phenotypic plasticity in life-history traits: predictions of reaction norms for age and size at maturity. Evolution 40:893-913

Trueman ER (1970) The mechanism of burrowing of the mole crab, Emerita. J Exp Biol 53:701-710

Underwood AJ (1990) Experiments in ecology and management: Their logics, functions and interpretations. Aust J Ecol 15:365-389

Veloso VG, Cardoso RS (1999) Population biology of the mole crab Emerita brasiliensis (Decapoda: Hippidae) at Fora Beach, Brazil. J Crustac Biol 19:147-153

Vermeij J, Zipser E (1986) Burrowing performance of some tropical Pacific gastropods. Veliger 29:200-206

Wenner AM (1988) Crustaceans and other invertebrates as indicators of beach pollution. In: Soule DF, Kleppel GS (eds) Marine organisms as indicators. Springer-Verlag, New York, p 199-229

Zar JH (1999) Biostatistical analysis. Prentice-Hall, Englewood Cliffs, NJ

Submitted: April 18, 2000; Accepted: July 13, 2000

Proofs received from author(s): February 16, 2001 